\title{
Conservation conflicts in nature conservation: the example of Kastamonu-Bartin Küre Mountains National Park
}

\section{Sevgi Görmüş}

Keywords: conservation conflicts, Küre Mountains National Park, Turkey

\section{Abstract}

Conservation conflicts arise for basically ecological, economic, social and safetyrelated reasons. There may occasionally be contradictions between people's desire to benefit from nature and conservation objectives.

National parks in Turkey are run to a very strict policy. Mainly as a result of problems arising from this policy, local people may experience different problems, sometimes these escalate into a conflict between authorities and local people living around the national parks.

In this study the contradictions between national, regional and local policies, objectives and strategies relating to nature conservation are evaluated alongside conservation and management plans in the case of Küre Mountains National Park (KMNP) in Turkey.

\section{Profile}

Protected area

Kastamonu-Bartin Küre

Mountains NP

Mountain range

Kure Dağları

Country

Turkey

\section{Conservation conflicts}

Disagreements between national, regional and local authorities on the one hand, and local communities and civil society organizations on the other, have an important place in conflict occurrence. Most of the rapidly developing conservation conflicts in conservation biology (Dickman 2010; Graham et al. 2011) focus on spatial land-use systems. Yet when the case history of conservation conflicts is examined, it becomes clear that management strategies and social factors are the most influential elements in the occurrence of conflicts (Dickman 2010; Linnell 2011). One of the most important reasons for the increase in conservation conflicts is that politics and regulatory mechanisms focus on natural components and remain incapable of social components evolution. In recent years there has been a growing interest in planning and legislation to determine suitable tools and techniques to evaluate social and natural components and to reconcile conflicting demands (Davies et al. 2010). One of these studies has been conducted by the Conservation Measures Partnership (CMP), a partnership of organizations and associations. The CMP has been seeking better ways and tools to design, manage and measure the impact of conservation efforts (Davies et al. 2010). According to the CMP (2013), quality of life, which is one of the most important elements of social components, has not been taken into consideration in decisionmaking processes and has been limited to situation analysis. However, social benefits and their results should be taken into consideration in conservation strategies and quality-of-life goals should be included in planning processes.
National parks contribute not only to serving biological diversity, ecosystem integrity and ecosystem service (Carey et al. 2000), but also to the sustainability of the local and regional economy, scientific studies, educational activities, ecotourism and traditional activities (Garcia-Frapolli et al. 2009; Toledo 2001; West \& Brockington 2006). Conservation conflicts are dense in national parks recently, particularly in Turkey.

National parks in Turkey are run to a very strict policy. Local people often suffer from a variety of problems arising from this policy. Sometimes these problems evolve into a conflict between authorities and local people living around the national parks. Moreover, national park policy has no ecotourism planning frame. So ecotourism or tourism activities produce negative effects and are a major pressure on the national park's natural landscape, according to the Rapid Assessment and Prioritization of Protected Area Management Tool (RAPPAM). Turkey is a country experiencing rapid socioeconomic changes on the natural environment. Protection laws take second place to economic development.

\section{Küre Mountains National Park (KMNP)}

The Kastamonu-Bartın Küre Mountains (Figure 1) were proclaimed a national park on 7 July 2000. In 2004 Küre Mountains National Park (KMNP) was selected as an area of extensification within the scope of the Biodiversity and Natural Resources Management project implemented in collaboration with the World Bank, financed by the Global Environment Fund (GEF) and executed by the Ministry of Environment and Forestry. After bilateral meetings initiated in 2004 between the Ministry of Forestry and Water Affairs 

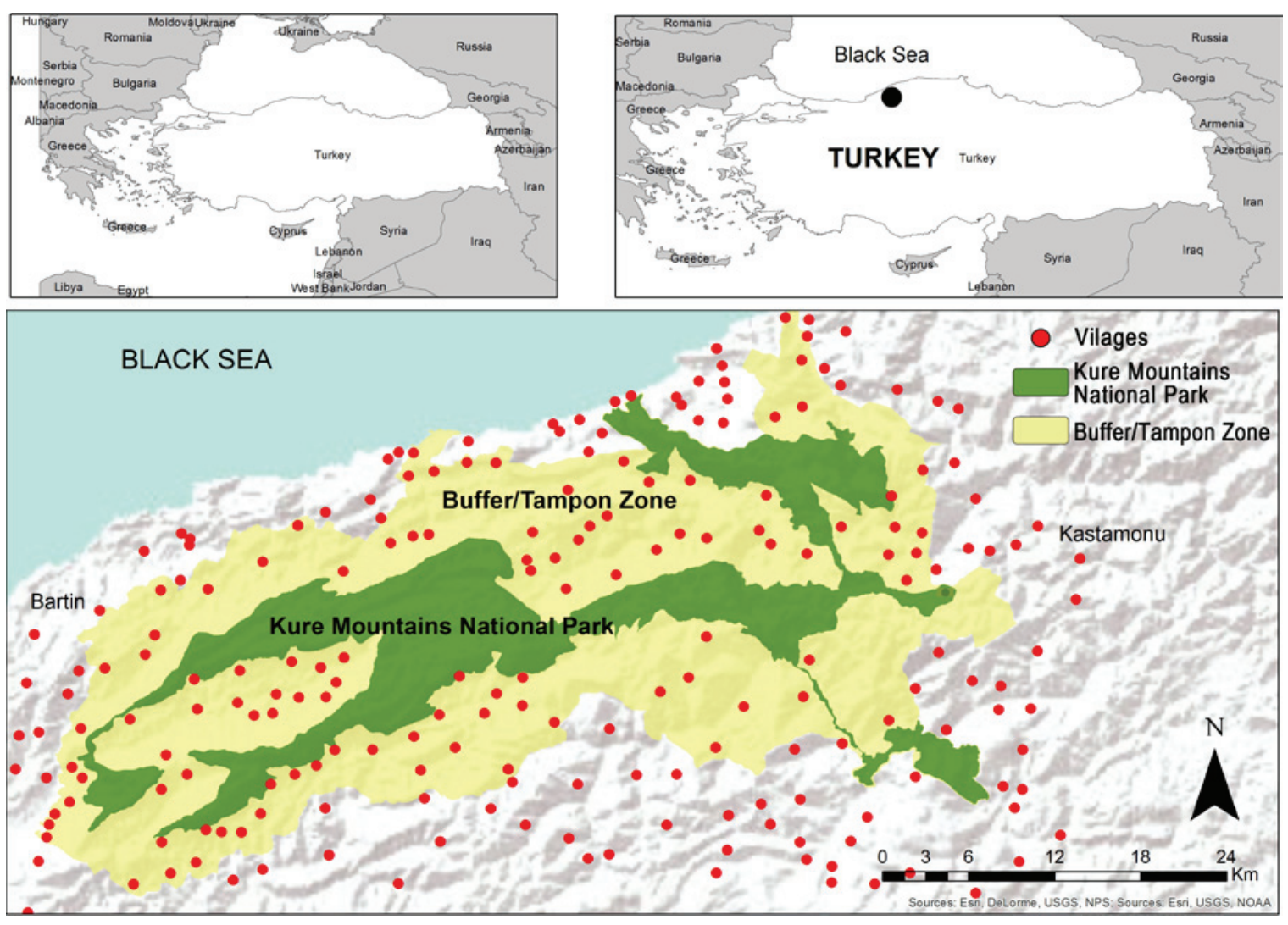

Figure 1 - The location of KMNP and the villages located around it (red points).

and PAN Parks, a letter of intent was signed on September 2006. In 2012 KMNP became the first PAN Park in Turkey; KMNP is recognized as part of the temperate forests of the Caucasus and Northern Anatolia, which are among the 200 ecoregions identified by the World Wildlife Fund (WWF) and the International Union for Conservation of Nature (IUCN). In 1999 the World Conservation Monitoring Centre (WCMC), the WWF and many experts identified over 100 forest areas in need of urgent preservation, most of which were located in the ecological regions of Europe and its surroundings. Among these Hot Spots of European Forests, nine are located in Turkey. The Küre Mountains are home to 40 of Turkey's 132 indigenous mammals, including such large species as the grey wolf, brown bear, Eurasian lynx, red deer, roe deer and wild boar. The park and its buffer zone are included on the list of 122 Important Plant Areas (IPA), and are also one of Turkey's 305 key biodiversity areas (KBA) (Anonymous 1999; WWF 2001; UNDP 2008; Bann 2010; Gormus 2012).

Among the reasons for the area being declared a national park are its international, national and regional significance. Its international and national significance lies in its old-growth forests, geological formations and fauna; its regional significance lies in its flora and its cultural, recreational and touristic value (Figure 2).

The KMNP management plan (Long-Term Development Plan), which was approved in 2012, divides the park into 5 regions: Strict Protection Area (Conser- vation zone), Sensitive Protection Area (Sensitive wild site), Sustainable Protected Area (Sustainable sites), Controlled Use Area (Controlled zone), and buffer zone. A buffer zone surrounding these areas has been identified where there is rural settlement density (Figure 2).

All of the settlements are located in buffer zone: There are eight towns and 122 villages within the boundaries of Kastamonu and Bartin. In total, 221000 people live around KMNP in settlements in the provinces of Kastamonu and Bartın. $30 \%$ of this population lives in urban areas and 70\% in rural areas (Turkish Statistical Institute 2014). While the total population of the villages in KMNP buffer zone was 29693 in 1990, this number had declined to 21384 by the year 2012.

According to results of the Management Effectiveness Monitoring Tool (METT), roads, plant collection, logging, dams and water resources management currently are among the severe threats in KMNP. Tourism and recreation areas, mining, roads, hunting, plant collection, canalization and waste water are among the most severe future threats.

According to RAPPAM results, the degree of pressure on the natural environment in KMNP increased sharply from 2005 to 2009, with national hydroelectric power plants and dams the main contributing factors. The RAPPAM report points out that KMNP has great socio-economic importance. It also states that the park is one of the areas where there is an increasing pressure on biological diversity (Stanciu 2009; 


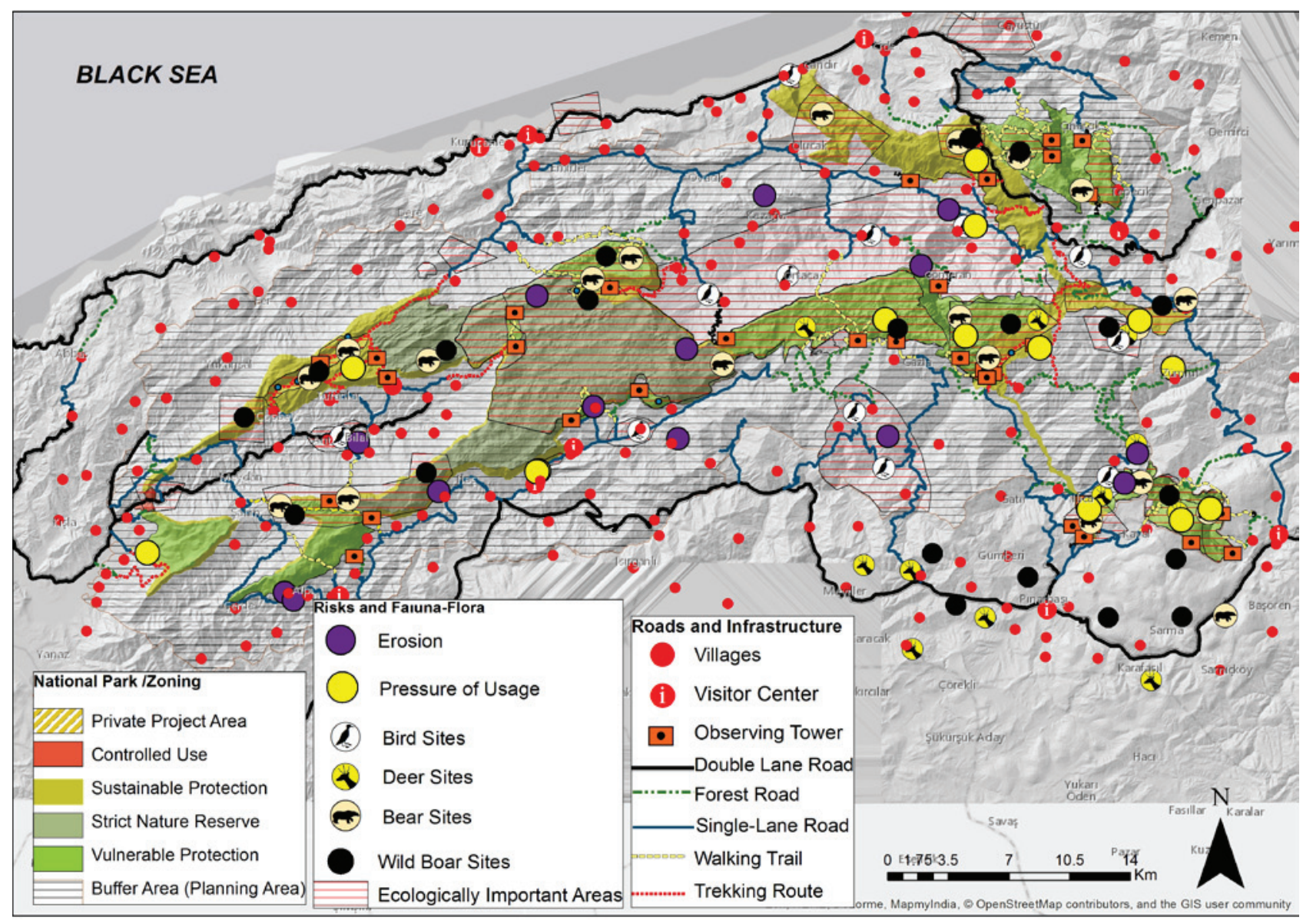

Figure 2 - Zoning, flora, fauna and infrastructure in KMNP.

Avcıoğlu Çokçalışkan et al. 2010). Mines and hydroelectric power plant construction are the main causes of this increasing pressure.

\section{Conservation conflicts in KMNP}

In KMNP conservation conflicts arise for basically ecological, economic, social and safety-related reasons. The main causes of the conflicts between locals' lifestyle, expectations and conservation objectives are groundwater and surface water pollution, habitat fragmentation, rural poverty and awareness problems. So, conservation conflicts in the area are not merely human-related. Management's planning approach and people's expectations may cause conflicts. For this reason conservation conflicts occur between wildlife, ecosystem diversity and quality of life. The conflicts between quality of life and ecosystem diversity are human / plant species conflicts; the conflicts between quality of life and wildlife are human/wildlife conflicts. The conflicts between quality of life and conservation objectives occur between the local community and institutions responsible for national park management. This last type of conflict arises because these institutions take precautions to protect the forest and wildlife. The most significant conflicts in the area occur between institutions and the local community, with institutional efforts to protect the environment leading to tension between local residents' quality of life and conservation objectives. When the ongoing conservation conflicts in the area are examined, human-wildlife conflicts also seem to be an issue, because both sides are affected negatively in this type of conflict.

It can be easily inferred from an evaluation of planned strategies, information obtained from local managers and local people that the conflict topics and reasons in national parks are directly affected by national policy and planning systems. The main conflict topics include water management (proposed construction of hydroelectric power plants in preservation areas of Turkey), management of gathering forest by-products, wildlife, feedback to local people and visitors, management capability and approach to resource planning. The conflicts are mostly seen in the national park buffer zone. As mentioned before there are important areas for wildlife and ecology in this buffer zone. Some places in this zone should be integrated with the preservation zone or critical or restricted usage areas, but they are all ignored. As a result the conflicts accumulate in this zone (Table 1).

When the issues, area and causes of conflicts in the KMNP are evaluated, it becomes clear that conflicts develop on three levels: micro-micro, micro-macro and macro-macro. Different types of strategies should 
Table 1 - Issues, area and causes of conflicts in KMNP.

\begin{tabular}{|c|c|c|}
\hline Conflict issue & Area & Causes of conflict \\
\hline Area management & NP buffer zone & $\begin{array}{l}\text { As the directorate of KMNP is not responsible for the buffer zone, the pressure on } \\
\text { the park caused by projects in this area is uncontrollable. }\end{array}$ \\
\hline Water management & NP buffer zone & $\begin{array}{l}\text { KMNP has significant mineral resources due to its geological structure. Pollution of } \\
\text { the water flowing from park to the buffer zone is a major threat to both surface and } \\
\text { underground water. }\end{array}$ \\
\hline Energy management & NP buffer zone & $\begin{array}{l}\text { Monitoring present/suggested energy investments, not involving KMNP manage- } \\
\text { ment in decision-making processes and having no power to reject these applica- } \\
\text { tions. }\end{array}$ \\
\hline $\begin{array}{l}\text { Management of non-timber forest } \\
\text { products }\end{array}$ & NP buffer zone & $\begin{array}{l}\text { Not following a plan or a programme to collect non-timber forest products causes } \\
\text { damage to both the local economy and biological diversity. }\end{array}$ \\
\hline Management of wildlife corridors & NP buffer zone & $\begin{array}{l}\text { As wildlife habitats in KMNP and the buffer zone are not evaluated with a wildlife } \\
\text { corridors approach and as present corridors are not protected, there are gaps } \\
\text { between corridors which cause a rise in encounters between humans and wild } \\
\text { animals. This is risky for habitats. }\end{array}$ \\
\hline \multirow[t]{2}{*}{ Lack of information } & NP buffer zone & $\begin{array}{l}\text { Not seeking ways to raise public awareness among the local people living in the } \\
\text { buffer zone to overcome prejudices about KMNP. }\end{array}$ \\
\hline & NP buffer zone & $\begin{array}{l}\text { Lack of national park information centres and entrance gates. Inactive information } \\
\text { centres. }\end{array}$ \\
\hline Weak capacity of area management & NP buffer zone & KMNP management's lack of personnel and experts. \\
\hline Irrelevant CSOs & NP buffer zone & Organizations' weakness in projects and lack of awareness. \\
\hline $\begin{array}{l}\text { The problem of locals' participation } \\
\text { in planning processes }\end{array}$ & NP buffer zone & $\begin{array}{l}\text { Not doing feasibility studies to realize the PAN Park process and not developing } \\
\text { strategies, private sector rather than local management of process risk. }\end{array}$ \\
\hline
\end{tabular}

be developed for each level to allow for effective conflict management (Table 2).

Conflict resolution will be hastened by considering approaches used in conflict management and identifying impacts, causes, levels and types of conflicts. Conservation objectives and quality of life objectives should be evaluated together in the relationship between area usage planning and the national park zoning system. Such mechanisms will allow both parties to gain, once they accept that enabling conservation is in their own interest and a mutually beneficial model will come to dominate.

The major threat to the residents of the local community is the loss of their livelihoods. They are highly dependent on KMNP, because there is a high level of rural poverty in the settlements in this area. This goes for all over Turkey. For this reason, the main cause of the conservation conflicts arising in national parks is again rural poverty. Together with rural poverty, national, regional and local policies, investments also contribute to conservation conflicts. Conservation conflicts in turn contribute to the increase in biological diversity sensitivity. The pressures created on national development goals, regional priorities and conservation objectives negatively affect both locals' livelihoods and biological diversity. The possible contradictions between national development plans and locals' main livelihoods will more and more frequently trigger an increase in the conflicts between local residents and the ecosystem and wildlife. Rising conflicts will in turn trigger an increase in biodiversity loss.

Changing ideas about protected land management to include both the protection of land and the protection of local social, economic and cultural values is a significant opportunity to enhance local residents' quality of life. This change in ideas will help alleviate conflicts between protected area management, central administrations, regional administrations, national / lo-

Table 2 - Significant regulations necessary to reduce conservation conflicts.

\begin{tabular}{|l|l|}
\hline Level of conflict & Strategies to reduce conflict \\
\hline \multirow{4}{*}{$\begin{array}{l}\text { Micro-micro: KMNP management } \\
\text { - local people }\end{array}$} & Finding technical solutions to reduce wildlife and human interactions. \\
\cline { 2 - 2 } & Developing a management and inspection system for the collection of forest by-products. \\
\cline { 2 - 2 } & Developing an agroforestry system to stop forest clear cutting. \\
\cline { 2 - 2 } & Developing projects related to the economy and infrastructure in order to enhance quality of life. \\
\hline $\begin{array}{l}\text { Micro-micro: KMNP management } \\
\text { - local NGOs }\end{array}$ & Developing conservation cooperation between locals and KMNP management. \\
\hline \multirow{4}{*}{$\begin{array}{l}\text { Micro-macro: among national } \\
\text { strategies }\end{array}$} & $\begin{array}{l}\text { Promoting equality of opportunity/economic equality to achieve the ecotourism activities proposed in } \\
\text { the PAN Parks process. }\end{array}$ \\
\cline { 2 - 2 } & Enabling the KMNP management to reject national strategies and polices. \\
\cline { 2 - 2 } & $\begin{array}{l}\text { Enabling cooperation between rules/regulations related to conservation and rules/regulations related } \\
\text { to development and enhancing quality of life, and allowing the rules and regulations related to con- } \\
\text { servation to be dominant. }\end{array}$ \\
\hline $\begin{array}{l}\text { Micro-macro: local administration } \\
\text { - NGOs }\end{array}$ & Developing cooperation among local NGOs, national NGOs and park management. \\
\hline $\begin{array}{l}\text { Macro-macro: among national } \\
\text { laws }\end{array}$ & $\begin{array}{l}\text { Resolving coordination problems between conservation, quality of life and strategies, regulations and } \\
\text { laws. }\end{array}$ \\
\hline
\end{tabular}


cal CSOs and the local community. It is therefore necessary to develop collaboration between the various parties involved.

Another reason is: There is no participatory approach in area planning and immediate prohibition of usage of local people in newly declared preservation areas. Since there is no alternative means of living provided and no consultation with local people, these prohibitive practices and preservation areas are seen as a negative phenomenon. With reference to KMNP, developing long-term development plans without a participatory approach leads to conflicts. Furthermore, long-term development plans drawn up without consulting the local people and agreeing on acceptable means of economic utilization will harm the relationship between local people and the national park. The same is true of solutions imposed without determining which activities the local people can perform and of uncertainty in the control of wild animals. While long-term development plans' zoning, aims and strategies are not realized, this also causes loss of trust in the national park management. Lack of trust reduces forest preservation activities on the part of the people and may lead them to disregard of the risk that may arise from the forest.

\section{References}

Anonymous 1999. Kure Mountains National Park, Development Plan. Prepared by the Ministry of Forestry (General Directorate of National Parks and GameWildlife) in collaboration with UNEP and FAO.

Avcıoğlu Çokçalışkan, B., Y. Lise \& E. Stanciu 2010. Protected Area Management Effectiveness in Turkey. Annual Journal of Rural Environment 2010: 110-129.

Bann, C. 2010. Enhancing forest protected areas system of Turkey, Developing a business plan for Küre Mountains National Park and its Buffer Zone, final report. Ankara.

Carey, C., N. Dudley \& S. Stolton 2000. Squandering Paradise? The Importance and Vulnerability of the World's Protected Areas. WWF-World Wide Fund for Nature (Formerly World Wildlife Fund) International, Gland, Switzerland.

CMP 2013. Conservation Measures Partnership, Open Standards For The Practice of Conservation, Version: 3. Available at: http://cmp-openstandards. org/wp-content/uploads/2014/03/CMP-OS-V3-0Final.pdf. (accessed: 03/08/2014)

Davies, Z.G., P. Kareiva \& P.R. Armsworth 2010. Temporal Patterns In The Size of Conservation Land Transactions. Conservation Letters 3 (1): 29-37.

Dickman, A.J. 2010. Complexities of Conflict: The Importance of Considering Social Factors For Effectively Resolving Human-Wildlife Conflict. Animal Conservation 13: 458-466.
García-Frapolli, E., G. Ramos-Fernández, E. Galicia \& A. Serrano 2009. The Complex Reality of Biodiversity Conservation Through Natural Protected Area Policy: Three Cases from the Yucatan Peninsula, Mexico. Land Use Policy 26: 715-722.

Gormus, S. 2012. Landscape character analysis for protected areas case study: Kastamonu Bartm Küre Mountains National Park. Dissertation, Ankara University, Graduate School Of Natural And Applied Sciences, Department of Landscape Architecture, Ankara.

Graham, I.M., R.N Harris \& S.J. Middlemas 2011. Seals, salmon and stakeholders: integrating knowledge to reduce biodiversity conflict. Animal Conservation 14: 604-607.

Linnell, J.D.C. 2011. Can We Separate The Sinners From The Scapegoats? Animal Conservation 14: 602-603.

Stanciu, E., B. Avcioğlu \& Y. Lise 2010. Korunan Alanlarda Hižl Değerlendirme ve Önceliklendirme: 2009 Sonuclar ve 2005 Yil Karşılaştırması. WWF-Türkiye, İstanbul.

Toledo, V.M. 2001. Indigenous People and Biodiversity. Encyclopedia of Biodiversity. Available at: http://enviro.doe.gov.my/lib/digital/13854737913-s2.0-B0122268652001577-main.pdf (accessed: 02/05/2013).

Turkish Statistical Institute 2014. Illerin Aldığ1, Verdiği Göç, Net Göç ve Net Göç Hızı, Genel Nüfus Sayımlar1 - ADNKS. Available at: http://www. tuik.gov.tr/UstMenu.do?metod=temelist (accessed: 02/03/2015)

UNDP 2008. Project Document GEF MSP PIMS 1988: Enhancing coverage and management effectiveness of the subsystem of forest protected areas in Turkey's national system of protected areas. Ankara.

West P. \& D.J. Brockington 2006. An Anthropological Perspective on Some Unexpected Consequences of Protected Areas. Conservation Biology 20 (3): 609-616.

WWF 2001. Mediterranean Forest: A New Conservation Strategy. Available at: http://d2ouvy59p0dg6k. cloudfront.net/downloads/brochure_english.pdf (accessed: 15 /07/2013)

\section{Author}

\section{Sevgi Görmüş}

is Assistant Professor at the Department of Landscape Architecture in the Faculty of Forestry at the University of Bartın, Turkey, and MSc student of Social Anthropology at the Social Sciences Institute of the University of Ankara, Turkey. Her research interests focus on landscape character, urban-rural interaction, national park planning, ecotourism and conservation conflicts. 